\title{
Preparing Women of Substance? Education, Training, and Labor Market Outcomes for Women in Pakistan
}

\author{
Monazza Aslam* and Shenila Rawal ${ }^{* *}$
}

\begin{abstract}
This paper investigates the economic (i.e., labor market) outcomes of "training" for individuals in Pakistan. The labor market benefits of general education have been relatively well explored in the literature and specifically in Pakistan. They point to the benefits of education accruing both from education or skills that promote a person's entry into more lucrative occupations and from raising earnings within any given occupation. This research delves into another angle by investigating the role, if any, of acquired "training" - technical, vocational, apprenticeship, or on-thejob-and its impact through both channels of effect on economic wellbeing. This is done using data from a unique, purpose-designed survey of more than 1,000 households in Pakistan, collected in 2007. Multinomial logit estimates of occupational attainment show how training determines occupational choice. In addition, we estimate the returns to schooling and to training separately for men and women. The results show that, while training significantly improves women's chances of entering self-employment and wage work (as well as the more "lucrative" occupations), only wage-working women benefit from improved earnings through the training they have acquired. On the other hand, men who have acquired skills this way benefit through an improved probability of being self-employed and earning higher returns within that occupation.
\end{abstract}

Keywords: Returns to schooling, vocational training, apprenticeship training, occupational choice, Pakistan.

JEL classification: I21, J16, J24.

\section{Introduction}

Individuals and firms undertake education and training as an investment to increase their earnings and productivity-the basic tenet of human capital theory (Becker, 1964). Within this context, the returns to general education, measuring the benefit (measured as increased

${ }_{* *}^{*}$ Institute of Education, University of London.

${ }^{* *}$ Institute of Education, University of London. 
earnings) of each additional year (or level) of schooling, have been the focus of immense research scrutiny. Education's critical role in determining and enhancing individuals' labor market outcomes is well documented in the literature.

Several recent studies on Pakistan have also shown this to be the case, for instance by showing that the labor market benefits of education and skills may accrue by facilitating entry to more lucrative occupations and, within occupations, by raising earnings. These associations, for example, have been investigated by Aslam, Kingdon, and Söderbom (2008) and more recently by Aslam, De, Kingdon, and Kumar (2012) who analyze the relationship between schooling and cognitive skills on the one hand, and occupational choice and earnings on the other. The authors find that education and skills significantly enhance individuals' chances of entering the more "rewarding" occupations and of raising their earnings within these occupations. This is especially true for women, suggesting that education can play a critical role in enhancing labor market outcomes for women in Pakistan. ${ }^{1}$

However, across the globe and particularly in Asia, the level of female participation in the labor force varies dramatically across countries and different contexts. According to the United Nations Development Programme, Pakistan ranked 146 out of 187 with a gender inequality rank of 115 out of $146 .{ }^{2}$ The country's female population accounts for 49.11 percent of the whole population and 63 percent of the rural population. Female labor participation is exceptionally low, with women in South Asia more likely to be involved in the agricultural sector and as unpaid workers compared to any other region in the world. For Pakistani women, as for other South Asian women, the decision to participate in the labor force is determined not only by market forces but, to a large degree, by nonmarket factors as well.

Having said this, female labor force participation is on the rise and is estimated to have increased from 13.9 percent in 1990 to around 23 percent in 2010. Nonetheless, compared to its South Asian counterparts, Pakistan's female labor force participation remains low. For example, it is 59.8 percent in Bangladesh, 83.1 percent in Nepal, and 68.2 percent in Bhutan

\footnotetext{
${ }^{1}$ However, the authors do note that women in Pakistan, both in rural and urban areas, begin to take advantage of the benefits of education only after about 10 years of schooling when they start undertaking wage work. This has important implications because very few women in Pakistan appear to have acquired 10 years of schooling or more, which means that only a relatively small proportion are able to take advantage of the benefits of schooling. Among men, in stark contrast, occupational choices are considerably more flexible with respect to education.

${ }^{2}$ http://hdrstats.undp.org/en/countries/profiles/pak.html
} 
(International Labour Organization [ILO] estimates from 2010). Within this context, studies such as Aslam, De et al. (2012) note that, while education can play a significant role in enhancing women's labor market outcomes, the existence of conservative cultures severely inhibits women's participation in productive activities. The constraints thus imposed on women are very apparent in analyses of labor markets in the region and specifically in Pakistan. Nevertheless, the consensus is that developing the human capital of a country, and specifically that of women, is a worthwhile investment.

Increasingly, research also indicates that human capital is embedded in an individual's ability to perform specific tasks, suggesting that there is a need to focus on the occupation-specific nature of human capital (Johnson \& Keane, 2007; Kambourov \& Manovskii, 2008). This, in turn, indicates that the labor market outcomes, variously measured, are likely to depend heavily on the skills individuals have learnt through general education and through any technical and vocational education (TVE), apprenticeship training, or on-the-job training acquired.

Despite this, there is no agreed consensus on how best these skills are conferred and debates abound about alternative routes through which labor market entrants' skills can be best developed. From a national perspective, increasing the skill base of the labor force is crucial to ensure efficiency and international economic competitiveness, particularly as the rate of increase of human capital formation is arguably more important than that of physical capital. In many developing countries, a large proportion of the workforce remains unskilled and many have skills that are not valued by employers. Skills development has, therefore, attracted policymakers' attention internationally over the last few decades.

Most educational systems around the world combine a "general" and "vocational" component in secondary schooling. However, these systems are organized very differently with varying degrees of emphasis placed on skills development through the latter. An undocumented number of individuals also undertake "apprenticeship training" where an employer or "mentor" undertakes to either employ a person (or engage without payment) and train him/her systematically in some trade for a fixed duration during the course of which the apprentice is bound to work in the master's service. Vocational education and training (VET) can be defined as "skill-based programs that focus on specific trades and impart the practical skills which allow individuals to engage in a specific occupational activity" (Agrawal, 2012). 
The current structure of vocational education and skill development programs in Pakistan is complex, with several agencies involved in providing skills and of different types. While government vocational institutes are administered by the provincial education departments, technical training centers and apprenticeship training centers are administered by the provincial labor departments. The provincial directorates of manpower and training administer apprenticeship training under the Apprenticeship Training Ordinance. Skills training is variously provided by polytechnic institutions, vocational training centers, apprenticeship schemes, training and vocational institutions under various ministries and departments, commercial training institutions, and through the ustad-shagird (mentor-apprentice) system in the informal sector (see Kazmi, 2007, for a useful summary).

This study aims to investigate the economic outcomes of training in Pakistan. In particular, we ask whether women who enter the labor market are equipped with skills that will not only benefit them by improving their occupational choices but also, eventually, by augmenting their earnings. The study is motivated by some major questions that have not yet been answered satisfactorily, such as the effects of training on economic outcomes in developing countries.

While there are many studies that estimate the economic rate of return to education in order to examine how much education is rewarded in the labor market (e.g., Aslam, 2009; Aslam, Bari, \& Kingdon, 2012), we are not aware of any such studies that compare this with the economic return to training. Since the household survey used in this study has collected detailed data on individuals' training, this study aims to fill the existing gap in the literature. Additionally, it is the first study we are aware of that investigates whether acquiring training promotes an individual's entry into certain occupations; analyzing this separately for males and females allows us to enrich the study. Finally, because the dataset includes earnings information on both wage- and self-employed individuals (unlike the usual household surveys that focus on wage earners alone), we can distinguish between the differential returns to training for the self-employed and wage-employed.

The paper is structured as follows: Section 2 provides an overview of the literature. Section 3 discusses the empirical methodology used and Section 4 describes the data and its key features. Section 5, which discusses the results, is divided into two subsections: the first part analyzes whether training determines occupational outcomes and the second examines the 
relationship between earnings, education, and training. Section 6 discusses our key findings and concludes the paper.

\section{Training: What We Know and Do Not Know}

Box 1 below summarizes the key channels through which "training" can be delivered. The mix will vary across different countries and, within them, across different regions. In some instances, one also expects certain channels of training to be available to certain demographic groups (younger versus older, male versus female) or those with particular characteristics (those having completed certain levels of general education or belonging to a particular socioeconomic group).

\section{Box 1: The five models of vocational training}

We start by looking at the models that have been used to deliver vocational skills.
There are five models:
Secondary school practical subjects-in some secondary school systems, students
have to take what are called "practical subjects" in addition to their traditional
academic subjects (e.g., geography, history, and so on). For example, in Zimbabwe,
students in secondary school often have to take two "practical" subjects. These
may include, agriculture, bricklaying, sewing (called "Fashion and Fabrics"),
cooking (called "Food and Nutrition"), technical drawing (draftsmanship),
woodwork, metalwork, and bookkeeping (accounting). Of course what subjects
are available to the students depends on the resources of the school: in order to
offer, say, metalwork, a school must have a metal workshop. We do not know of
any evaluation of the impact of these practical subjects.
Apprenticeships-this involves learning a trade on the job. We do not know of an
evaluation of apprenticeship programs.
Technical trade school and apprenticeship-in this model, vocational training is given
as a form of "tertiary" or post-secondary education. Students that do not continue
on the academic track after secondary school go to what are sometimes called
"technical colleges" where they learn a trade. Specialties include mechanics
(aircraft, train, automotive), accounting, construction, secretarial, boilermaker, and
electrician. These are formal schools on par with (primary) teachers' college,
agricultural college, and nursing college. The training can take years. Because it
aims to produce professional artisans who will work in the formal sector, the
classroom learning is often combined with an apprenticeship in industry. The
colleges can be private or public.
We know of two evaluations of this model, both of them in Latin America (Peru
and Colombia).
Community recreational centers-some community recreational centers will have,
along with other recreational facilities, staffed workshops where people can learn
certain skills, such as carpentry, welding, typing, sewing, wound dressing, and so
on. The courses are often very short and geared towards the one skill. (A good way


to think of these training centers is to think of recreational hobby shops at some American colleges, where students can go and work wood or make jewelry under guidance from the shop manager.) These are often available in urban communities. We do not know of any evaluations of this model.

Livelihoods training - this is often given by NGOs and other groups in the community (such as religious groups or women's groups). The focus is on teaching incomegenerating activities, such as how to produce goods (batiks, knitwear, soap, clothes, cookware, cups, dishes made from salvaged metal); enterprises at local markets; and small-scale import and export (for example, women from Zimbabwe would take their batiks to South Africa by bus, sell them there, and buy goods to resell in Zimbabwe). NGOs in South Asia have used this model to train girls, for example, on cultivating crops and vegetables, poultry farming, poultry and livestock vaccination, tailoring, hairdressing and other non-agricultural businesses.

Source: Glennerster and Takavarasha (2010).

Evidence on the "returns" to training is not as vast as that investigating general primary education. Measuring the benefit of training to the individual is analogous to estimating the return to education. The problems with measuring the impact of training are not very different from those faced when measuring returns to general education. Specifically, endogeneity bias (the best workers acquire more training and would earn more anyhow) and survival bias (the best firms train more workers and tend to be the ones that survive) are the two key methodological constraints to econometric analysis.

To some extent, these problems can be overcome by allowing for a worker's ability, family background, and early schooling in estimated equations. Firm-level studies also include the characteristics of the firm, while others use various econometric techniques to try to account for any other unobservable differences between trained and untrained workers, which lie at the heart of the endogeneity problem. In addition to these underlying concerns, the existence of externalities at the industry and national level (benefits to other workers, industries, etc., particularly if poaching is a major problem) also constrain estimation.

Much of the developing country research on the impact of training has looked at the role of vocational training and is based in Latin America. Evaluations there have shown that vocational training linked to apprenticeships can improve the earning and employment outcomes of individuals. However, the research on Asia, where different labor market conditions exist, is far more limited and, therefore, presents weighty grounds for further investigation along the lines of this paper. 
From the limited evidence that does exist for Asia, the findings are not very encouraging. For example, a report by the World Bank (2008) found that the labor market outcomes of those with vocational training in India were not good and that a high proportion of those with VET remain unemployed long after they have completed their courses. Similarly discouraging results were found by the ILO (2003) efficiency/impact study of industry training institutes and industrial training centers in three Indian states. This evidence is often also combined with the perception that VET is a "second-tier education" associated with lowpaid or low-status jobs and for those who cannot gain admission to perceived higher-quality academic institutions.

Generally, vocational training programs are shown to be most effective for those at the higher end of the wage distribution. Vocational training in a trade school and combined with an apprenticeship has been shown to work for both males and females in Latin America. Moreover, when the relative returns to training in male- relative to female-dominated trades are explicit, it can increase female enrolment in such courses, e.g., mechanics, information technology, etc. (Glennerster \& Takavarasha, 2010).

There is also more evidence that confirms that combining technical training with apprenticeships can be effective. For example, the Jovenes en Accion in Columbia evaluation finds that women spent more time on training and that the program increased employment chances, chances of employment in the formal sector, the probability of contract work, and the number of days and hours worked. The employment effects were found to be smaller for men. The study also found that the program improved wages for both men ( 8 percent) and women (18 percent). The internal rate of return for women (14 percent) was found to be higher than that for men (5 percent) (Attanasio, Kugler, \& Meghir, 2008).

Another randomized study of technical training in Peru (Pro Joven) has similar positive results for vocational training. Nonrandomized evaluations of the program, however, found no differences in the hourly wages of men and women, although employment rates and the extent of occupational segregation differed for both. Training was found to have a greater impact on women's employment rates (15.2 percent) than that of men (11 percent) (Nopo, Robles, \& Saavedra, 2007). Finally, another randomized evaluation of vocational training in Kenya was conducted to investigate whether providing young people with vouchers to attend a trade school of their choice had positive effects for those involved (Hjort, Kremer, Mbiti, \& Miguel, 2011). It found that providing women with 
simple and actionable information on the relative returns to femaledominated trades (compared to male-dominated trades) increased their enrolment in the higher-return, male-dominated courses by 10 percent.

The evidence outside the randomization literature is also convincing. For example, Agrawal's (2012) study on vocational education in India uses a large-scale, nationally representative household survey (National Survey Sample Organization) to examine the labor market outcomes of general secondary school graduates compared to those who have received vocational training. The study finds a relatively high rate of unemployment (11 percent) for those in the age group 15-29 that have acquired VET. However, while this unemployment rate is higher than that for those in the age group as a whole, it is smaller than for those who have a general secondary qualification. VET graduates are found to have higher average daily wages whether they are casual or regular workers. Agrawal also highlights the large number of training institutions that have emerged recently, although he indicates that there are regional and state disparities in coverage.

In a study on Indonesia, Newhouse and Suryadarma (2009) note that private vocational school graduates fare at least as well as private general graduates, despite coming from more disadvantaged socioeconomic backgrounds. The returns to public vocational education, however, appear to have declined sharply for the most recent cohort of men in Indonesia. According to the authors, this is cause for concern, given the expansion of public vocational education and the relevance of the male vocational curriculum in an increasingly service-oriented economy.

Evidence from the UK hints at the benefits of adult education and training. Feinstein, Galindo-Rueda, and Vignoles (2004) use a very rich dataset that includes early-ability tests and looks at the number of workrelated training spells lasting more than three days. The study finds that 47 percent of males and 36 percent of females received training. It also finds that training has a 4-5 percent impact on wage growth for males aged 3342; the gain for the trained group (when taking into account that firms tend to cherry-pick those for training) is high (12 percent) but there is no potential gain for the untrained group. The results for females, however, are not robust: while the authors do not find training to affect wage growth for females in this age bracket, they do note the large impact of training on wages at age 42 . 
Deardon, McIntosh, Myck, and Vignoles (2000) find that additional returns associated with academic qualifications (without taking into account the time taken to gain those qualifications) are typically higher than those associated with vocational qualifications at the same level in the UK. When the time taken is included, the annual returns to vocational qualifications move closer on average to those accruing from academic qualifications. The study also finds gender differences: women tend to earn more for academic qualifications but the gender bias for vocational qualifications depends on the different types of qualifications with women's vocational returns being highest for teaching and nursing. Greenwood, Jenkins, and Vignoles (2007) also find that there are high returns to academic qualifications across the board in the UK, but there are also substantial returns to higher-level vocational qualifications and smaller but not insignificant returns to some, but not all, intermediate and lower-level vocational qualifications.

At a macro-level, studies show strong differences among countries in the probability of being enrolled in vocational schooling. Altinok (2012) uses data from the Program for International Student Assessment (PISA) 2009 to show that the probability of being enrolled in the general or vocational stream depends heavily on gender, family education, socioeconomic status, immigrant status, repetition rate, and reading for enjoyment. He finds that pupils in vocational schools perform significantly lower than those in general education schools in most countries. While pupils with a high socioeconomic status are significantly more likely to be enrolled in general education, standard characteristics such as gender, family education, and a proxy for motivation explain about a third of pupils' achievement differences between the two streams.

Evaluations of VET have also focused on the long-run impact on employment and earnings. Krueger and Kumar (2004a, 2004b) argue that the propensity to use vocational rather than general education may be an underlying cause of growth rate differentials between the US and Europe. This, the authors argue, is due to vocational or "skill-based" education as opposed to general education-"concept-based" education leading to slower adoption of new technologies.

Hanushek, Woessmann, and Zhang (2011) use a sample pooling individuals from 18 countries and find that general education improved individuals' employment probability as they become older relative to those with vocational education. However, they do find differences across countries with the US, Canada, and Chile showing patterns where the 
employment probability of individuals with different types of education does not vary with age at all, whereas this is not the case in most of the European countries in the sample.

Far fewer studies have focused exclusively on comparisons of apprenticeship training versus vocational training as a form of acquiring skills. Using developed country data, Parey (2009) shows that firm-based apprenticeship training leads to substantially lower unemployment rates than vocational training. Investigating this pattern over time, the evidence indicates that former apprentices have only a transitory advantage. The study does not, however, find a significant difference in wages between those with vocational or apprenticeship training. This suggests that these alternatives confer similar overall levels of productivity, and that apprenticeship training improves the early labor market attachment relative to vocational schooling.

The literature base evaluating training in the labor market in Pakistan is very limited. Most studies are primarily descriptive and discuss how technical, vocational, or apprenticeship training is provided and has evolved within the country. A joint study by the Pakistan government and UNESCO discusses the various efforts made to encourage technical schooling in Pakistan in recent years (Pakistan, Ministry of Education, and UNESCO, 2009). These include a bid to incorporate TVE subjects at the secondary level of education, the launching of specific projects, and the desire to create model vocational schools. On the whole, most of these efforts have failed due to a shortage of facilities (laboratories and equipment) and qualified teachers, lack of commitment, and political instability, among other factors.

The study also highlights the fact that, as in other sectors of education in Pakistan, TVE is plagued by issues of access as well as quality. In practical terms, it barely meets demand with the consequence that not enough individuals benefit from skills development through this channel. Additionally, when they do access this stream, issues of poor quality arising from the little time spent preparing students and limited, outdated curricula undermine the value of any such training acquired. A key factor attributed to the poor access and quality of TVE in the country appears to be the fragmented structure of governance in training institutions. The study clearly reflects the need for a national curriculum framework to guide appropriate TVE (see Pakistan, Ministry of Education, and UNESCO, 2009). We are not aware of any quality study in Pakistan that has looked at the role of training for men and women separately. 


\section{Empirical Methodology}

The association of "training" with earnings may operate through several channels such as improving access to lucrative occupations or, conditional on occupational attainment, by raising earnings within any given occupation. In this study, we explore the relationship between training and occupational attainment as well as the total effect of training on earnings, conditioned on general education.

The first of these employs a form of multinomial regression analysis. All sampled labor market participants in the dataset are classified under one of five occupational categories: (i) out of the labor force, (ii) unemployed, (iii) unpaid family workers, (iv) self-employed, and (v) wageemployed. Unemployed individuals are those who seek employment and are available for it, while those out of the labor force are those who do not seek employment, such as homemakers, fulltime students, and retirees. In South Asia, often more than one household member may be working in a family farm or nonfarm household enterprise, in which case we define the person reported to be the primary worker or decision maker as selfemployed. If any other family member reports separate earnings from the work, they are considered wage workers and the rest are considered unpaid family labor.

The second part of the paper presents earnings functions of the form

$$
\operatorname{Ln} Y_{i}=\beta_{0}+\beta_{1} S_{i}+\beta_{2} X_{i}+\beta_{3} \text { Training }_{i}+\varepsilon_{i}
$$

The earnings regressions use data from wage- and self-employed individuals in the labor market. For each of the wage-employed, we have data on earnings and on the likely explanatory variables. So, in (1), $\operatorname{Ln} Y_{i}$ is the natural $\log$ of annual earnings for individual $i, S_{i}$ measures the years of completed schooling, $X_{i}$ is a vector of observed characteristics of individual $i$ (such as age and its square), and Training is a dummy variable that takes the value of 1 if an individual reported ever acquiring technical or vocational schooling, on-the-job training, or working as an apprentice. $\varepsilon_{i}$ is an individual-specific error term. In this specification, $\beta_{1}$ reflects the return to schooling while $\beta_{3}$ captures the return to training (technical, vocational, on-the-job, or apprenticeship).

Since one of our objectives is to estimate the total returns to education, the variables included as regressors in the multinomial logit (MNL) and earnings function models differ. In the MNL models, the 
regressors include age (and its square), years of completed schooling and its square, state, location, number of household members younger than 15 years and number older than 60, and whether married or not. Cognitive test scores are included in some MNL models. In addition, we include a measure of "training" to assess the extent to which acquiring training assists entry into certain occupations. The MNL models are estimated separately for men and women to allow for gender-differentiated effects.

The regressors used in the earnings function estimates include education, age and its square, and regional and state fixed effects. As in the MNL models, "training" is included as an additional regressor to assess the returns to training, if any. The earnings functions are derived through ordinary least squares (OLS) regression analysis, and yield lower-bound estimates of the rates of return to education and training. Mincerian functions are estimated separately for all men and women engaged in wageor self-employment, and then separately for wage- and self-employment.

We recognize that the OLS earnings function estimates potentially suffer from two major biases: sample selectivity and endogeneity (omitted variable) bias. The first stems from estimating the earnings function for separate subsamples of workers, each of which might not be randomly selected. However, evidence from previous estimates has shown this not to be a major concern in Pakistan (Aslam, 2009).

The second problem, omitted variable bias, is potentially more problematic. Human capital theory posits that additional years of schooling and training raise worker productivity, consequently increasing earnings in the labor market. Thus, the coefficient of schooling/training in the earnings function is interpreted as the causal effect of education/training on earnings, giving the expected percentage gain in earnings with an additional year of schooling/training. However, this is valid only if earnings differentials between individuals with varying years of schooling/training do not reflect differences in unobserved ability that happen to be correlated with education/training. ${ }^{3}$ Unobserved inherent ability is clearly a determinant of schooling attainment/training as well as of earnings. While omitted ability induces an upward bias in the estimated

\footnotetext{
${ }^{3}$ Boissiere, Knight, and Sabot's (1985) study of two East African countries (Kenya and Tanzania) distinguishes among the effects on earnings of cognitive skills, native ability, and years of schooling as a means of adjudicating between the human capital, screening, and credentialist views. Using purpose-built establishment data for 1980 from the two countries, the authors conclude that the returns to numeracy and literacy in the two countries are large, and they attribute these to a payment to human capital. The authors also find that the direct returns to native ability are small, suggesting a refutation of the screening hypothesis, at least for their sample.
} 
return due to a positive correlation between schooling and the error term, it is not clear whether the direction of bias is the same in the case of training as measured in this paper.

Thus, the endogeneity of schooling and training stems from unobserved heterogeneity: more able or motivated individuals may "choose" to acquire more general education and more or less certain types of training. One approach to overcoming endogeneity is to use repeated observations for the same individual over time or observations for different individuals within the same family to "difference out" the variables generating correlation in the residuals. Arguably, a good part of the unobserved heterogeneity is common to family members. Consequently, differences in unobserved ability and their impact in determining education should be lower within rather than between families.

Earnings functions can be estimated for twin samples, siblings, and father-son or mother-daughter pairs, using a "fixed effects" or firstdifferencing approach. By introducing subsamples of households with at least two individuals of a given gender in wage- and self-employment (and, more stringently, households with brothers or sisters and father-son or mother-daughter pairs in wage-employment), the fixed-effects method effectively controls for all household variables that are common across these individuals within a given household.

A simultaneous advantage of the fixed-effects procedure is that it eliminates the sample selection problem. In order to address the potential endogeneity of schooling and training in earnings function estimates, we generate household fixed-effects estimates. However, because of the potentially small sample of women within a household who are wage- or self-employed earners, the gender-differentiated analysis is not based on significant confidence. The estimates are, however, reported in the Annex (Table A3). Our analysis, therefore, discusses the OLS estimates with the view that the results are broadly descriptive rather than causal.

\section{Data and Descriptive Statistics}

This study uses data from two main sources. In the first instance, to document the status of men and women in the labor force, we use data from the Labor Force Survey (LFS) for two points in time-2000 and 2008. This allows us to provide a nationally representative overview of how men and women aged 15-60 are distributed across activity status (labor force participants versus nonparticipants) and within the labor force across 
different occupational categories (unemployed, unpaid workers, selfemployed, or wage workers). The LFS data also allow us to investigate the "incidence of technical and vocational training" at the national level. ${ }^{4}$

The LFS data is supplemented by another data source: the Research Consortium on Educational Outcomes and Poverty (RECOUP) household survey conducted in Pakistan between November 2006 and March 2007. The survey was administered to 1,194 urban and rural households selected randomly through stratified sampling from nine districts in two provinces (Punjab and Khyber Pakhtunkhwa [KP]). ${ }^{5}$

The RECOUP survey collected basic demographic, anthropometric, education, and labor market status information on all resident household members in the sampled households (more than 8,000 individuals), Detailed individual-level questionnaires were administered only to those aged between 15 and 60 years. Some 4,907 individual-level questionnaires were thus filled. Tests were also administered to assess these individuals' literacy, numeracy, health knowledge, and English language skills. For literacy and numeracy, two types of instruments were used to capture "basic-order" skills and "higher-order" skills.

In our analysis, we have used the scores of the "short literacy test" and "short numeracy test," each consisting of five questions. In addition to these questions, one section of the questionnaire was dedicated to asking detailed questions about the incidence of technical/vocational schooling, apprenticeship training, and any on-the-job training received. The instruments, therefore, allowed for a very nuanced version of "training" to include apprenticeship training; although the drawback of the RECOUP data is that they are not nationally representative, the very rich information available allows us to define "training" to include the three different types defined above. Additionally, the RECOUP dataset includes information on the earnings of self-employed individuals (not available in most household datasets, including the LFS), and this allows us to determine whether the returns to training are different for wage- and self-employed men and women in Pakistan's labor markets.

\footnotetext{
${ }^{4}$ The incidence of training is taken to be equal to 1 if the person reports having answered "yes" to the question, "Has... ever completed any technical or vocational training such as auto or engine mechanics, carpentry, typing, computer, tailoring, etc.?” and 0 otherwise.

${ }^{5}$ In Punjab, the following districts were sampled: Sargodha, Kasur, Attock, Chakwal, Rahimyar Khan, and Khanewal; in KP (then NWFP), Charsadda, Swat, and Haripur were sampled.
} 
The following question asked of all individuals aged 15-60 is of most interest to us: "Has [sampled individual] ever (i) attended technical/vocational college, (ii) worked as an apprentice, and (iii) received any on-the-job training?" Responses to these variables were precoded to take on a value of 1 if the individual answered "yes" and 0 otherwise. Respondents were asked additional detailed questions to collect information on the "types" of skills acquired, the duration of training received, and the type of college/institution/setting where it was received. All enumerators were trained and provided with the following definition of apprenticeship: "Classify someone as an 'APPRENTICE' if they were/are working in a firm/environment where a formal/informal arrangement exists with the employer such that they teach that individual certain skills-regardless of whether they receive no payment, or fixed-rate or piece-rate payments." The uniqueness of these data allows us to investigate this very interesting issue in Pakistan.

We proceed by documenting the status of women in the labor force, followed by a more in-depth analysis of training. Table 1 gives the summary statistics for labor market status by gender, comparing the LFS for 2000 and 2008 with the RECOUP 2007 dataset. The extent of gender asymmetry in the distribution of the labor force is striking. In Pakistan, about 70 percent of women were out of the labor force compared to 8 percent of men in 2007.

Table 1: Distribution of labor force (aged 15-60) by gender (percent)

\begin{tabular}{lcccccccccc}
\hline & \multicolumn{3}{c}{ LFS 2000 } & \multicolumn{3}{c}{ LFS 2008 } & \multicolumn{3}{c}{ RECOUP 2007 } \\
\cline { 2 - 10 } & All & Male & Female & All & Male & Female & All & Male & Female \\
\hline $\begin{array}{l}\text { Pakistan } \\
\text { Out of the labor force }\end{array}$ & 54.0 & 20.1 & 88.7 & 49.3 & 18.4 & 81.2 & 39.0 & 8.0 & 69.0 \\
In the labor force & 46.0 & 79.9 & 11.3 & 40.7 & 81.6 & 18.7 & 61.0 & 92.0 & 31.0 \\
Of those in the labor force & & & & & & & & & \\
Unemployed & 1.6 & 1.7 & 1.5 & 1.2 & 1.1 & 1.9 & 13.0 & 7.0 & 31.0 \\
Unpaid family workers & 18.1 & 14.4 & 44.9 & 26.7 & 18.7 & 62.4 & 18.0 & 12.0 & 34.0 \\
Agriculture a & & & & & & & 8.0 & 11.0 & 0.3 \\
Self-employed & 39.8 & 43.3 & 14.9 & 34.3 & 39.1 & 12.9 & 20.0 & 22.0 & 15.0 \\
Wage workers & 40.4 & 40.7 & 38.7 & 37.9 & 41.3 & 22.8 & 41.0 & 48.0 & 20.0 \\
\hline
\end{tabular}

a The RECOUP dataset allows us to distinguish between the self-employed in agriculture and those in nonagriculture.

Sources: RECOUP data based on samples from Punjab and KP; LFS data based on all provinces (the RECOUP-Pakistan survey for 2006/07 is based on only two). 
While the proportion of women in the labor force appears to have improved over the seven-year period, this must be interpreted cautiously as the LFSs are nationally representative while the RECOUP data only covers two provinces. Even when they are in the labor force, women are significantly more likely to be in unremunerated occupations (as unpaid family workers) with only about 20 percent of women in Punjab and KP engaged in wage-employment. In fact, this figure is not very different from the national average of about 23 percent, according to the LFS for 2008, giving credence to the view that women are, on average, underrepresented in lucrative occupations and over-represented in ill-paid or nonpaying ones, both according to the LFS (2000 and 2008) and the RECOUP (2007) datasets.

Table 2 summarizes the incidence of training as defined in the LFS, i.e., technical and vocational training, by year, age group, and gender. The two key points to note in this table are that the incidence of training has increased over an eight-year period and the significant pro-male gender gap in the acquisition of training appears to have diminished, especially among the younger cohort. Overall, in 2008, 8.2 percent of all men aged 15-60 reported having acquired any technical or vocational training compared to 6.7 percent of women.

Table 2: Incidence of training by age, gender, and year (LFS 2000 and 2008) (percent)

\begin{tabular}{|c|c|c|c|c|c|c|c|c|c|}
\hline \multirow[b]{2}{*}{ Ever received } & \multicolumn{3}{|c|}{$\begin{array}{c}\text { Young } \\
\text { (15-30 years) }\end{array}$} & \multicolumn{3}{|c|}{$\begin{array}{c}\text { Older } \\
\text { (31-60 years) }\end{array}$} & \multicolumn{3}{|c|}{$\begin{array}{c}\text { All } \\
\text { (15-60 years) }\end{array}$} \\
\hline & Male & Female & & Male & Female & & Male & Female & \\
\hline Any training (2000) & 3.0 & 1.1 & $* * *$ & 3.9 & 0.1 & $* * *$ & 3.4 & 1.0 & $* * *$ \\
\hline Any training (2008) & 7.5 & 7.3 & & 8.9 & 5.9 & $* * *$ & 8.2 & 6.7 & $* * *$ \\
\hline
\end{tabular}

Notes: "Any training" is defined as someone who reported having undergone any duration of technical or vocational schooling.

*** = significant at 1 percent.

Source: Authors' computations from LFS 2000 and 2008.

As mentioned before, the RECOUP data allow us to differentiate between three categories of training: technical/vocational, apprenticeship, and on-the-job training. Table 3 summarizes the distribution of individuals aged 15-60 who reported having undertaken any such type of training. 
Table 3: Incidence of training by gender and age (RECOUP) (percent)

\begin{tabular}{|c|c|c|c|c|c|c|c|c|c|}
\hline \multirow[b]{2}{*}{ Ever received } & \multicolumn{3}{|c|}{$\begin{array}{c}\text { Young } \\
\text { (15-30 years) }\end{array}$} & \multicolumn{3}{|c|}{$\begin{array}{c}\text { Older } \\
\text { (31-60 years) }\end{array}$} & \multicolumn{3}{|c|}{$\begin{array}{c}\text { All } \\
\text { (15-60 years) }\end{array}$} \\
\hline & Male & Female & & Male & Female & & Male & Female & \\
\hline Vocational training & 9.4 & 10.4 & $* *$ & 10.5 & 7.1 & $* * *$ & 9.9 & 8.8 & \\
\hline Apprenticeship training & 16.0 & 19.4 & $* * *$ & 15.7 & 16.7 & & 15.8 & 18.2 & $* *$ \\
\hline On-the-job training & 3.8 & 1.2 & * & 3.8 & 2.1 & $* *$ & 3.7 & 1.5 & $* * *$ \\
\hline $\begin{array}{l}\text { Any training (vocational } \\
\text { and/or apprenticeship } \\
\text { and/or on-the-job) }\end{array}$ & 23.1 & 26.2 & * & 23.6 & 24.7 & & 23.3 & 24.3 & \\
\hline
\end{tabular}

Note: ${ }^{*}=$ significant at 10 percent, ${ }^{* *}=$ significant at 5 percent, ${ }^{* * *}=$ significant at 1 percent. Source: Author's computations from RECOUP 2007

First, it must be noted that the RECOUP data reveals a somewhat higher proportion of women who reported receiving technical and vocational training compared to that reported in the LFS data: almost 10 percent of all women aged 15-60 reported having acquired this form of training in 2007 compared to about 7 percent according to the LFS 2008. This minor difference in "incidence" could just indicate a substantially higher incidence of this type of training among women in Punjab and KP. Nevertheless, we take comfort from the fact that the national average of incidence of technical/vocational training is not very different from what we find in the RECOUP data.

Second, the summary statistics in Table 3 reveal the strikingly large incidence of apprenticeship training - a kind of training not even captured in the LFS. A significantly large proportion of women, especially young women (19.4 percent), report having undertaking apprenticeship training. Finally, the incidence of on-the-job training is low and there appears to be a pro-male bias in its incidence.

The very high reported incidence in the two provinces covered by RECOUP is somewhat surprising. We are aware of only one other study on Pakistan that has looked at apprenticeship training in Punjab: Asghar and Siddi (2008) note that, compared to European countries, Pakistan (as indicated by the data on Punjab) displays a very low percentage of young people undergoing apprenticeships (less than 1 percent). In the UK, this proportion is 14 percent; in Germany, 57 percent; in France, 15 percent; and in Ireland, 9 percent. The authors attribute Pakistan's low percentage to lack of awareness, poor quality, lack of standardization, the passive 
attitude of employers, and lack of vertical mobility among VET graduates. Our data, however, finds evidence to the contrary.

Table 4 investigates descriptive associations from another angle. "Training" is combined into a single component and individuals who reported having received any kind of training (technical/vocational, apprenticeship, or on-the-job) fall under "ever trained." The incidence of this is reported with respect to that individual's completed level of general education. The table reports these associations differentiated by age cohort and by gender.

Broadly speaking, the incidence of training depicts a monotonic increase with respect to education level, and this holds for all individuals and separately for the young and older age groups. For instance, among all male 15-60-year-olds, 41 percent who have completed a BA or more in general education report having been "ever trained" compared to 15 percent of those with no education. It is also worth noting that the incidence of training is significantly higher among all young women compared to young men. It is also significantly higher among young women with no education and those who have completed middle school (eight years), and among older women who have completed their matriculation (10 years) compared to men with similar qualifications. These patterns hint at the exit points at which training is usually undertaken and specifically by women-no education, after completing middle school, and after completing their matriculation exams.

Table 4: Incidence of training (apprenticeship, vocational, on-the-job), by general education level, gender, and age

\begin{tabular}{|c|c|c|c|c|c|c|c|c|c|}
\hline \multirow[b]{2}{*}{ Education level } & \multicolumn{3}{|c|}{$\begin{array}{c}\text { Young } \\
\text { (15-30 years) }\end{array}$} & \multicolumn{3}{|c|}{$\begin{array}{c}\text { Older } \\
\text { (31-60 years) }\end{array}$} & \multicolumn{3}{|c|}{$\begin{array}{c}\text { All } \\
\text { (15-60 years) }\end{array}$} \\
\hline & Male & Female & & Male & Female & & Male & Female & \\
\hline None & 13.8 & 20.9 & $*$ & 15.0 & 17.9 & & 14.6 & 19.2 & ** \\
\hline Any primary & 23.0 & 23.1 & & 22.3 & 21.1 & & 22.7 & 22.4 & \\
\hline Middle & 14.6 & 28.3 & $* * *$ & 22.0 & 29.7 & & 17.8 & 28.7 & $* *$ \\
\hline Matriculation & 31.3 & 36.8 & & 30.2 & 59.1 & $* * *$ & 30.8 & 42.4 & $* * *$ \\
\hline Intermediate & 41.8 & 42.1 & & 43.9 & 66.7 & & 42.7 & 45.5 & \\
\hline BA or above & 38.9 & 51.7 & & 42.1 & 46.2 & & 40.9 & 50.7 & \\
\hline All & 23.1 & 26.2 & * & 23.6 & 24.7 & & 23.3 & 24.3 & \\
\hline
\end{tabular}

Notes: Education categories are defined in terms of years of schooling as follows: none $=0$ years; any primary $=1,2,3,4,5,6$, or 7 years; middle $=8$ or 9 years; matriculation $=10$ or 11 years; intermediate $=12$ or 13 years; BA or above $=14$ or more years.

${ }^{*}=$ significant at 10 percent, ${ }^{* *}=$ significant at 5 percent, ${ }^{* *}=$ significant at 1 percent. Source: Authors' calculations. 
Finally, Figure 1 illustrates the "types" of skills acquired by men and women aged 15-60 in Punjab and KP. ${ }^{6}$ The gender differentiation in skills acquisition is most apparent from this figure, which reveals that while men acquire a reasonably broad range of skills, women are restricted to certain types of skills. On the whole, women are largely represented in teaching, nursing, crafts-making, dressmaking, and tailoring. Men, on the other hand, also train as "mechanics" and "electricians" and acquire other "professional skills."

This is an interesting insight into the dynamics of skills training as the eventual "return" to a certain kind of training should, surely, depend not only on the quality of the skills acquired but also on the demand for those skills. Fasih (2008), for instance, argues that policies aimed at improving the skills of the workforce will not have a significant impact on the earnings of those who acquire the skills-and eventually on economic growth-unless policies exist that increase the demand for those skills. She cites the example of Ghana where the demand for labor is largest in the domestic market where the return to skills is very low. However, the supply of individuals entering the domestic market outstrips the demand, which ensures that the price of skills (in this case, low-educated labor) is inevitably low. This hints at the need to address the issue of job creation-creating enough jobs that utilize the skills developed and ensuring that these jobs are of a minimum quality. We turn to this issue later on in the paper.

\footnotetext{
${ }^{6}$ Training here excludes on-the-job training.
} 
Figure 1: Types of skills acquired during training (apprenticeship/vocational) by gender (RECOUP 2007)

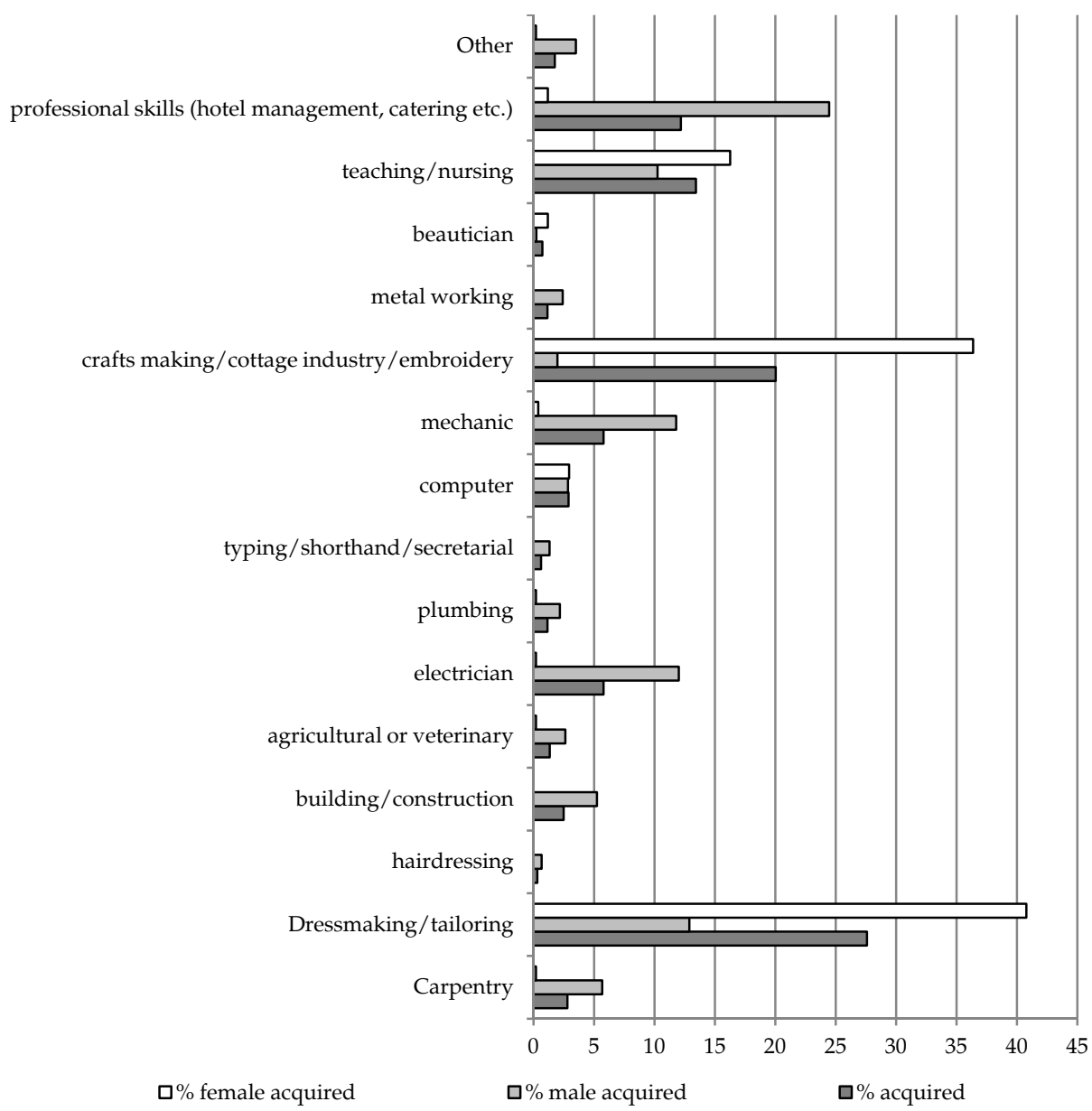

Source: Authors' computations based on RECOUP (2007).

Summarizing the findings so far, we note that, when the definition of "training" is broadened to include apprenticeship training, the incidence of training is significantly high, at least in Punjab and KP where the RECOUP data allows an analysis. In particular, we note that a significantly large number of women acquire such training compared to men. However, women appear to be limited to the acquisition of certain types of skills; the majority acquire skills that lead to teaching, nursing, crafts-making, tailoring, or dressmaking. Whether acquiring this training affects women's labor market outcomes positively-both in terms of their occupational choices and their earnings-is an empirical question that we turn to in the next section. 


\section{Empirical Findings}

\subsection{Training and Occupational Attainment}

This subsection investigates whether one of the ways in which the labor market benefits of human capital accrue is by promoting entry into more lucrative occupations. We do this by looking at the effect of training (defined as "ever trained" if person has reported ever acquiring TVE, apprenticeship training, and/or on-the-job training) on occupational outcomes. As discussed earlier, we define five "occupations" using the data and analyze the case of men and women separately. The key variable of interest is "training" to determine whether having ever acquired any training is positively associated with the likelihood of entering a more lucrative occupation or with deterring an individual from entering a less lucrative one.

The analysis is undertaken by means of simple, parsimoniously specified MNL models (see Section 3). Tables 5 and 6 depict the marginal effects (and the associated $\mathrm{z}$-values) of the independent variables estimated separately for men and women. The dependent variable is occupational choice, which takes on one of the following values: 1 (out of the labor force), 2 (unemployed), 3 (unpaid worker), 4 (self-employed), or 5 (wage-employed). The base outcome is whether the individual is out of the labor force.

While Aslam et al. (2008) and Aslam, Bari et al. (2012) investigate whether education and skills (as defined by cognitive skills) acquisition improve labor market outcomes in Pakistan, our study differs in a key way in that, for the first time we are aware of, this kind of study has been undertaken to evaluate the association between "training" and occupational choice and subsequent earnings.

Table 5 reports the marginal effects for men aged 15-60 based on an MNL model estimated for activity status. We control for general education and its square and for "training" along with the standard controls reported in the table. Table 6 replicates the model for women. Comparing the two tables, it is clear that the estimated vector of coefficients varies greatly by gender. In terms of our key variable of interest, having acquired any training significantly improves the likelihood of men entering selfemployment while reducing their likelihood of being unpaid workers. For example, the relative probability that a trained male will be self-employed increases by about 7 percent while the relative probability that he will be an 
unremunerated worker falls by about 3 percent. Training clearly appears to benefit men in terms of improving their chances of being self-employed and reducing the probability that they will be unpaid.

The results in Table 6, which replicates these models for women, are even more interesting. It appears that trained women are significantly less likely to be out of the labor force and significantly more likely to be self-employed or engaged in wage work. Somewhat surprisingly, they are significantly more likely to be "unpaid." On closer inspection, however, this finding is not completely surprising as trained women may have a greater likelihood of being absorbed into family-run businesses as unpaid workers if they have acquired skills that are compatible with the business needs. The most striking results, however, are that trained women are 15 percent less likely to be out of the labor force and correspondingly almost 9 percent more likely to be engaged in some form of paid self-employment and 4 percent more likely to be paid wage-workers. Training thus substantially drives women's exit from the least lucrative "out of the labor force" category and promotes their entry into lucrative self-employment and wage work.

As a robustness check, we apply an alternative specification conditioned on "cognitive skills" as measured by individuals' scores on literacy and numeracy tests (both the short math and literacy test scores range from 0 to 5). These results are reported in the Annex (Tables A1 and A2). The pattern of results remains largely unchanged, especially for women: acquiring training improves their chances of entering selfemployment and wage employment and reduces the likelihood that they are entirely out of the labor force. That the occupational outcomes of training so strongly indicate beneficial effects for both men and womenand especially for women-is a heartening result. However, do these also translate into better earnings, conditioned on schooling? We turn to this question in the following section. 
Table 5: MNL model: Marginal effects, men aged 15-60

\begin{tabular}{|c|c|c|c|c|c|c|c|c|c|c|c|c|c|c|c|}
\hline \multicolumn{16}{|c|}{ Probability of being... } \\
\hline & \multicolumn{3}{|c|}{ Out of the labor force } & \multicolumn{3}{|c|}{ Unemployed } & \multicolumn{3}{|c|}{ Unpaid } & \multicolumn{3}{|c|}{ Self-employed } & \multicolumn{3}{|c|}{ Wage-employed } \\
\hline & $\begin{array}{c}\text { Marginal } \\
\text { effect }\end{array}$ & z-value & & $\begin{array}{c}\text { Marginal } \\
\text { effect }\end{array}$ & z-value & & $\begin{array}{c}\text { Marginal } \\
\text { effect }\end{array}$ & z-value & & $\begin{array}{c}\text { Marginal } \\
\text { effect }\end{array}$ & z-value & & $\begin{array}{c}\text { Marginal } \\
\text { effect }\end{array}$ & z-value & \\
\hline Education & 0.007 & 1.61 & & 0.005 & 1.33 & & 0.000 & 0.00 & & 0.016 & 2.08 & $* *$ & -0.028 & -3.43 & $* * *$ \\
\hline Education ${ }^{2}$ & -0.001 & -2.22 & $* *$ & 0.000 & -0.75 & & 0.000 & -0.08 & & -0.002 & -2.76 & $* * *$ & 0.003 & 4.29 & $* * *$ \\
\hline Age & -0.008 & -2.29 & $* *$ & -0.009 & -2.79 & $* * *$ & -0.007 & -1.44 & & 0.023 & 2.99 & $* * *$ & 0.000 & 0.06 & \\
\hline Age $^{2}$ & 0.000 & 3.55 & $* * *$ & 0.000 & 2.58 & $* *$ & 0.000 & 0.00 & & 0.000 & -1.88 & * & 0.000 & -0.76 & \\
\hline Kidsunder15 & 0.000 & 0.01 & & 0.000 & -0.09 & & 0.007 & 4.90 & $* * *$ & 0.003 & 0.92 & & -0.010 & -2.59 & $* *$ \\
\hline Eldove60 & 0.016 & 2.05 & $* *$ & -0.007 & -0.96 & & 0.004 & 0.54 & & -0.009 & -0.56 & & -0.004 & -0.26 & \\
\hline Married & -0.058 & -2.77 & $* * *$ & -0.044 & -2.48 & ** & -0.020 & -1.37 & & 0.086 & 2.71 & $* * *$ & 0.037 & 1.07 & \\
\hline Punjab & -0.043 & -2.88 & $* * *$ & -0.039 & -2.90 & $* * *$ & 0.023 & 2.10 & $* *$ & 0.036 & 1.43 & & 0.023 & 0.84 & \\
\hline Urban & 0.018 & 1.25 & & -0.002 & -0.17 & & 0.000 & -0.01 & & -0.015 & -0.58 & & -0.001 & -0.03 & \\
\hline Ever trained & -0.013 & -0.98 & & -0.016 & -1.49 & & -0.033 & -2.95 & $* * *$ & 0.069 & 2.48 & $* *$ & -0.006 & -0.21 & \\
\hline$\overline{\mathrm{N}}$ & 1,866 & & & & & & & & & & & & & & \\
\hline Pseudo-R² & 0.100 & & & & & & & & & & & & & & \\
\hline $\mathrm{p}$ (chi-squared) & 0.000 & & & & & & & & & & & & & & \\
\hline
\end{tabular}

Notes: Robust Z-statistics; ${ }^{*}=$ significant at 10 percent, ${ }^{* *}=$ significant at 5 percent, ${ }^{* * *}=$ significant at 1 percent or better.

Base category $=$ out of the labor force. Education is measured as a continuous variable and ranges from 0 to 18 . Education ${ }^{2}=$ square of education. Age is measured in continuous years. Age ${ }^{2}=$ square of age. Kidsunder15 = number of children in household aged 15 or below. Eldove60 = number of adults in household aged 60 or above. Married = 1 if individual is married, 0 otherwise. Punjab $=1$ if person resides in Punjab, 0 if resides in KP. Urban $=1$ if residence is urban, 0 otherwise. Ever trained $=1$ if person reports having ever acquired any training (defined as technical or vocational training, apprenticeship training, and on-the-job training). 
Table 6: MNL model: Marginal effects, women aged 15-60

\begin{tabular}{|c|c|c|c|c|c|c|c|c|c|c|}
\hline \multicolumn{11}{|c|}{ Probability of being... } \\
\hline & \multicolumn{2}{|c|}{ Out of the labor force } & \multicolumn{2}{|c|}{ Unemployed } & \multicolumn{2}{|c|}{ Unpaid } & \multicolumn{2}{|c|}{ Self-employed } & \multicolumn{2}{|c|}{ Wage-employed } \\
\hline & $\begin{array}{c}\text { Marginal } \\
\text { effect }\end{array}$ & z-value & $\begin{array}{c}\text { Marginal } \\
\text { effect }\end{array}$ & z-value & $\begin{array}{c}\text { Marginal } \\
\text { effect }\end{array}$ & z-value & $\begin{array}{c}\text { Marginal } \\
\text { effect }\end{array}$ & z-value & $\begin{array}{c}\text { Marginal } \\
\text { effect }\end{array}$ & z-value \\
\hline Education & 0.007 & $1.75^{*}$ & -0.001 & -0.46 & -0.008 & $-3.74^{* * *}$ & -0.001 & -0.81 & -0.003 & $2.75^{* * *}$ \\
\hline Education $^{2}$ & -0.001 & $-2.95^{* * *}$ & 0.001 & $3.56^{* * *}$ & 0.000 & 0.28 & 0.000 & 0.18 & 0.000 & $3.46^{* * *}$ \\
\hline Age & -0.017 & $-2.98^{* * *}$ & 0.004 & 0.83 & 0.000 & -0.17 & 0.006 & $2.58^{* *}$ & 0.008 & $3.10^{* * *}$ \\
\hline $\mathrm{Age}^{2}$ & 0.000 & $2.88^{* * *}$ & 0.000 & -0.98 & 0.000 & -0.02 & 0.000 & $-2.49 * *$ & 0.000 & $-2.52 * *$ \\
\hline Kidsunder15 & -0.012 & $-3.99 * * *$ & 0.005 & $2.61 * *$ & 0.004 & $3.41^{* * *}$ & -0.001 & -0.63 & 0.003 & $2.89^{* * *}$ \\
\hline Eldove60 & 0.024 & $1.93 *$ & 0.001 & 0.16 & 0.002 & 0.40 & -0.007 & -1.36 & -0.021 & $-3.73^{* * *}$ \\
\hline Married & 0.126 & $4.64^{* * *}$ & -0.044 & $-2.15^{* *}$ & -0.004 & -0.41 & -0.037 & $-2.84^{* * *}$ & -0.041 & $-3.11^{* * * *}$ \\
\hline Punjab & -0.182 & $-9.49 * * *$ & 0.029 & $2.07^{* *}$ & 0.093 & $8.66^{* * *}$ & 0.029 & $3.81^{* * *}$ & 0.031 & $4.17^{* * *}$ \\
\hline Urban & 0.078 & $3.70^{* * *}$ & -0.031 & $-2.09 * *$ & -0.066 & $-6.41^{* * *}$ & 0.023 & $2.27^{* *}$ & -0.004 & -0.53 \\
\hline Ever trained & -0.151 & $-6.01^{* * *}$ & -0.006 & -0.38 & 0.030 & $2.69^{* * *}$ & 0.089 & $5.48^{* * *}$ & 0.037 & $3.19^{* * *}$ \\
\hline $\mathrm{N}$ & 2,043 & & & & & & & & & \\
\hline Pseudo-R2 & 0.142 & & & & & & & & & \\
\hline $\begin{array}{l}\mathrm{p}(\text { chi- } \\
\text { squared })\end{array}$ & 0.000 & & & & & & & & & \\
\hline
\end{tabular}

Notes: Robust $z$-statistics; ${ }^{*}=$ significant at 10 percent, ${ }^{* *}=$ significant at 5 percent, ${ }^{* * *}=$ significant at 1 percent or better.

Base category $=$ out of the labor force. Education is measured as a continuous variable and ranges from 0 to 18 . Education ${ }^{2}=$ square of education. Age is measured in continuous years. Age ${ }^{2}=$ square of age. Kidsunder15 = number of children in household aged 15 or below. Eldove60 = number of adults in household aged 60 or above. Married $=1$ if individual is married, 0 otherwise. Punjab $=1$ if person resides in Punjab, 0 if resides in KP. Urban $=1$ if residence is urban, 0 otherwise. Ever trained $=1$ if person reports having ever acquired any training (defined as technical or vocational training, apprenticeship training, and on-the-job training). 


\subsection{Education, Training, and Earnings}

This subsection starts by investigating the wage increment that accrues across wage- and self-employed individuals from each extra year of schooling and from whether an individual has acquired any training. This is done by estimating and comparing the marginal rates of return to general education supplemented by "ever trained." We use the familiar Mincerian earnings function approach where the coefficient of "years of schooling" measures the rate of return to each additional year of schooling, and the coefficient of the binary training variable indicates the marginal benefit in terms of additional earnings for someone who has acquired any training compared to someone who has not. ${ }^{7}$ Table 7 reports the results for all individuals and separately for males and females. The overall return to an additional year of schooling in this sample is about 4 percent, i.e., each additional year of schooling increases lifetime earnings, on average, by 4 percent.

Table 7: Earnings functions for all wage- and self-employed individuals (aged 15-60) and by gender

\begin{tabular}{|c|c|c|c|c|c|c|}
\hline \multirow[b]{2}{*}{ Ln(earnings) } & \multicolumn{2}{|c|}{ All } & \multicolumn{2}{|c|}{ Male } & \multicolumn{2}{|c|}{ Female } \\
\hline & Coefficient & t-value & Coefficient & t-value & Coefficient & t-value \\
\hline Education & 0.044 & $6.15^{* * *}$ & 0.025 & $3.20^{* * *}$ & 0.094 & $6.17^{* * *}$ \\
\hline Age & 0.106 & $6.53^{* * *}$ & 0.094 & $5.88^{* * *}$ & 0.132 & $2.51 * *$ \\
\hline Age2 & -0.001 & $-5.74^{* * *}$ & -0.001 & $-5.32 * * *$ & -0.002 & $-2.02 * *$ \\
\hline Punjab & -0.068 & -0.95 & 0.018 & 0.25 & -0.110 & -0.60 \\
\hline Urban & 0.003 & 0.05 & 0.091 & 1.66 * & -0.158 & -1.01 \\
\hline Ever trained & 0.014 & 0.24 & 0.190 & $3.57^{* * *}$ & -0.032 & -0.20 \\
\hline Constant & 8.598 & $30.25^{* * *}$ & 8.988 & $31.79^{* * *}$ & 7.118 & $8.37^{* * *}$ \\
\hline $\mathrm{N}$ & 1511 & & 1290 & & 221 & \\
\hline $\mathrm{R}^{2}$ & 0.100 & & 0.100 & & 0.228 & \\
\hline
\end{tabular}

Note: Robust t-statistics; ${ }^{*}=$ significant at 10 percent, ${ }^{* *}=$ significant at 5 percent, ${ }^{* * *}$ significant at 1 percent or better.

There is a striking difference between men and women in the returns to additional years of schooling-an additional year of schooling increases women's lifetime earnings by about 9 percent compared to less than a third ( 2.5 percent) for men. These findings are completely consistent

\footnotetext{
${ }^{7}$ Although equations with the education-squared term were also estimated, the term was insignificant in most cases, indicating that, in these specifications, education has a linear impact on earnings.
} 
with previous evidence from Pakistan and indicate that acquiring an additional year of schooling benefits women significantly.

We focus now on the key variable of interest-"ever trained." Unlike the evidence on returns to schooling, we do not find corresponding benefits in terms of improved earnings for women who have acquired any training. Men who have acquired training, however, earn 19 percent more over their lifetimes than those who have not (conditioned on general education).

Tables 8 and 9 explore this interesting anomaly further by estimating earnings functions separately for the self-employed and wageemployed. Table 8 shows that, among self-employed men, education confers no "return" while training yields a huge 33 percent return, i.e., selfemployed men who have acquired any training earn 33 percent more than those who have not done so. However, while additional years of schooling confer large returns to self-employed women (about 9 percent), the acquisition of training yields no such apparent return.

Table 8: Earnings functions for all self-employed individuals (aged 1560) and by gender

\begin{tabular}{|c|c|c|c|c|c|c|}
\hline \multirow[b]{2}{*}{ Ln(earnings) } & \multicolumn{2}{|c|}{ All } & \multicolumn{2}{|c|}{ Male } & \multicolumn{2}{|c|}{ Female } \\
\hline & Coefficient & value & Coefficient & value & Coefficient & value \\
\hline Education & 0.042 & $2.43^{* *}$ & -0.003 & -0.14 & 0.093 & $3.44^{* * *}$ \\
\hline Age & 0.133 & $4.13^{* * *}$ & 0.085 & $2.46^{* *}$ & 0.154 & $1.85^{*}$ \\
\hline $\mathrm{Age}^{2}$ & -0.002 & $-3.89 * * *$ & -0.001 & $-2.58^{* * *}$ & -0.002 & -1.62 \\
\hline Punjab & -0.064 & -0.41 & 0.075 & 0.45 & -0.276 & -0.83 \\
\hline Urban & 0.125 & 1.06 & 0.240 & 1.93 * & 0.370 & 1.46 \\
\hline Ever trained & 0.042 & 0.41 & 0.332 & $3.24^{* * * *}$ & -0.083 & -0.34 \\
\hline Constant & 7.901 & $12.90^{* * *}$ & 9.140 & $13.54^{* * *}$ & 6.762 & $5.14^{* * *}$ \\
\hline $\mathrm{N}$ & 616 & & 516 & & 100 & \\
\hline $\mathrm{R}^{2}$ & 0.100 & & 0.100 & & 0.260 & \\
\hline
\end{tabular}

Note: Robust t-statistics; ${ }^{*}=$ significant at 10 percent, ${ }^{* *}=$ significant at 5 percent, ${ }^{* * *}=$ significant at 1 percent or better.

Table 9 replicates the results for wage workers. While an additional year of schooling increases a wage-working male's (female's) earnings by about 4 (6) percent, the acquisition of training yields large beneficial effects only for women and not for men. Having acquired any training increases wage-working women's earnings by about 35 percent compared to women 
with no training. ${ }^{8}$ However, this effect is only just significant at the 10 percent level.

Table 9: Earnings functions for all wage-employed individuals (aged 15-60) and by gender

\begin{tabular}{lcccccc}
\hline & \multicolumn{1}{l}{ All } & \multicolumn{2}{c}{ Male } & \multicolumn{2}{c}{ Female } \\
\cline { 2 - 7 } Ln(earnings) & Coefficient t-value & \multicolumn{1}{c}{ Coefficient t-value } & Coefficient t-value \\
\hline Education & 0.040 & $7.76^{* * *}$ & 0.039 & $8.34^{* * *}$ & 0.060 & $2.81^{* * *}$ \\
Age & 0.088 & $6.30^{* * *}$ & 0.086 & $6.85^{* * *}$ & 0.095 & 1.40 \\
Age $^{2}$ & -0.001 & $-5.29^{* * *}$ & -0.001 & $-5.82^{* * *}$ & -0.001 & -1.08 \\
Punjab & -0.083 & -1.64 & -0.031 & -0.64 & 0.071 & 0.34 \\
Urban & -0.080 & -1.56 & 0.012 & 0.27 & -0.406 & $-2.09^{* *}$ \\
Ever trained & 0.033 & 0.66 & 0.061 & 1.34 & 0.352 & $1.66^{*}$ \\
Constant & 9.007 & $39.23^{* * *}$ & 9.073 & $42.47^{* * *}$ & 7.945 & $7.24^{* * *}$ \\
\hline $\mathrm{N}$ & 895 & \multicolumn{5}{c}{121} \\
$\mathrm{R}^{2}$ & 0.150 & \multicolumn{7}{c}{0.183} & & 0.200 \\
\hline
\end{tabular}

Note: Robust t-statistics; ${ }^{*}=$ significant at 10 percent, ${ }^{* *}=$ significant at 5 percent, ${ }^{* *}=$ significant at 1 percent or better.

What do these results imply? In order to examine this issue, we reestimate the equations in Tables 7, 8, and 9 with "training" differentiated into its components (TVE, apprenticeship training, and on-the-job training)..$^{9}$ The key findings from this differentiation are, first, that the large positive returns to "training" for men (both wage- and self-employed) are due to the high positive returns to "apprenticeship training." Second, among women, the large positive returns (35 percent) among wage workers are captured entirely in the training acquired through TVE. Therefore, the channels through which the benefits from training accrue in the form of raised earnings differ by gender.

\section{Discussion of Results and Conclusion}

In the context of Pakistan, we have addressed the question of whether "training" confers any labor market benefits to individuals who undertake it and whether the benefits are differentiated by gender.

\footnotetext{
${ }^{8}$ Table A3 in the Annex reports the fixed-effects functions, controlling for schooling and training. The samples are limited to at least two males or two females within a household who report being either wage- or self-employed. However, the samples are very small, especially among women, and we do not have much confidence in the precision of the estimates. The findings are, therefore, not discussed.

${ }^{9}$ The results are not reported due to space constraints.
} 
This study has corroborated what we know very well about the Pakistani labor market: a large majority of women are out of the labor force and, hence, economically inactive. Among those who are in the labor market, very few are represented in the more lucrative and rewarding occupations (wage work followed by self-employment). This is contrary to how men are distributed in the labor market. From previous work, we also know that general education can induce equality-women who acquire more education not only enter the more lucrative occupations but also face higher returns in the form of increased earnings (see Aslam, Bari et al., 2012; Aslam et al., 2008; Aslam, De et al., 2012). However, only women with very high levels of schooling (more than eight years) can take advantage of its labor market benefits, and only a very small proportion of women in Pakistan have actually acquired this level of education.

Another route that is often available to less-educated workers is TVE or the acquisition of some form of apprenticeship training. Within the context of a labor force constrained by cultural barriers to women's participation in paid work and low levels of education (and, hence, skills), the potential role of any such training in determining occupational choice and improvements in earnings becomes very interesting. This study has attempted, therefore, for the first time to address these questions in the context of Pakistan.

The evidence presents several key findings. We find that both men and women benefit significantly from having acquired any training. Women in particular are not only significantly less likely to be out of the labor force but are also significantly more likely to be self-employed or engaged in wage work. Thus, acquiring training promotes men and women's entry into more lucrative occupations.

For women, the return to an additional year of schooling is significantly larger than that for men, suggesting that the labor market rewards to additional schooling for women are substantial. However, while training aids women's entry into more lucrative occupations, earnings benefits are also differentiated by gender-training increases men's earnings substantially when they are self-employed and women's earnings when they are wage-employed. A clue to this difference lies in the fact that self-employed men's returns derive entirely from having acquired apprenticeship training, while the benefits to women in the form of higher wages occur through their acquisition of TVE. Thus, men with apprenticeship training as opposed to those without earn significantly more when self-employed. Women with technical or vocational training earn significantly more than those without, when engaged in wage work. 
Our findings shed light on several policy angles. The study's evidence leads us into the policy discussion on how best to prepare individuals who exit general education at various points for the labor market. Different approaches compete with each other (and also depend on the level of general education completed): firm- or employer-based apprentices, fulltime or part-time vocational education, or on-the-job training.

We are not aware of any studies to date that have highlighted the extent to which training affects labor market outcomes for men and women in Pakistan, and the relative effectiveness of different types of training in the form of improved earnings. This paper has documented how training can prove a beneficial pathway for men and women to gain entry into lucrative occupations. It has also shown how apprenticeship training and vocational schooling in particular can benefit men and women in the form of raised earnings. This hints at the need to effectively develop institutions that undertake this important mechanism of skills training in the country.

Additionally, much of the debate in the international literature has focused on the relative merits of general versus vocational or other training. However, our evidence implies that training confers benefits independent of general schooling. Thus, providing quality training at different exit points from general education can improve labor market outcomes, especially for women. However, this should not detract us from the fact that more quality empirical research is needed to understand the optimal mix of general schooling and occupation-specific training in order to better evaluate the relative advantages of different types of skills acquisition.

Existing studies on TVE in Pakistan have, time and again, called for the need to spread quality technical and vocational schooling in the country to reduce unemployment and boost economic growth (Pakistan, Ministry of Education, \& UNESCO, 2009). These studies emphasize the need to revamp existing TVE institutions and create inter-linkages between these institutions and the industry. Kazmi (2007) argues that public expenditure on vocational education needs to be increased manifold from the current level. She also notes that institutional arrangements need to be strengthened to address governance issues and public-private partnerships created to end the reliance of the existing TVE system on the public sector, which may be hindering both access and effective skills development.

Finally, it is worth reiterating that, as Fasih (2008) points out, while improving the quality and quantity of skills should be part of a good 
educational policy package, these need to be combined with effective labor market policies that address the issue of job creation. Without enough quality jobs that match the skills created with labor market needs, educational packages-no matter how comprehensive and dynamic-will not succeed. 


\section{References}

Agrawal, T. (2012). Vocational education and training in India: Challenges, status and labor market outcomes. Journal of Vocational Education and Training, 64(4), 453-474.

Altinok, N. (2012). General versus vocational education: Some new evidence from PISA 2009 (Background paper for the Education for All Global Monitoring Report 2012: Youth and skills: Putting education to work). Paris, France: UNESCO.

Asghar, W., \& Siddi, S. H. (2008). Apprenticeship training in Pakistan: A comparative study of apprenticeship practices in Punjab and European countries. International Journal of Training Research, 6(2), $1-19$.

Aslam, M. (2009). Education-gender gaps in Pakistan: Is the labor market to blame? Economic Development and Cultural Change, 57(4), 747-784.

Aslam, M., Bari, F., \& Kingdon, G. (2012). Returns to schooling, ability and cognitive skills in Pakistan. Education Economics, 20(2), 139-173.

Aslam, M., De, A., Kingdon, G., \& Kumar, R. (2012). Economic returns to schooling and cognitive skills: A South Asian comparison. In C. Colclough (Ed.), Education outcomes and poverty: A reassessment (pp. 94-118). London, UK: Routledge.

Aslam, M., Kingdon, G., \& Söderbom, M. (2008). Is female education a path to gender equality in the labor market? Some evidence from Pakistan. In M. Tembon \& L. Fort (Eds.), Educating girls for the 21st century: Gender equality, empowerment and economic growth (pp. 6792). Washington, DC: World Bank.

Attanasio, O., Kugler, A., \& Meghir, C. (2008). Training-disadvantaged youth in Latin America: Evidence from a randomized trial (Working Paper No. 13931). Cambridge, MA: National Bureau of Economic Research.

Becker, G. S. (1964). Human capital. New York, NY: Columbia University Press.

Boissiere, M., Knight, J. B., \& Sabot, R. H. (1985). Earnings, schooling, ability, and cognitive skills. American Economic Review, 75(5), 1016-1030. 
Dearden, L., McIntosh, S., Myck, M., \& Vignoles, A. (2000). The returns to academic and vocational qualifications in Britain. London, UK: Centre for the Economics of Education.

Fasih, T. (2008). Linking education policy to labor market outcomes. Washington, DC: World Bank.

Feinstein, L., Galindo-Rueda, F., \& Vignoles, A. (2004). The labor market impact of adult education and training: A cohort analysis (Discussion Paper No. CEEDP0036). London, UK: Centre for the Economics of Education.

Glennerster, R., \& Takavarasha, K. (2010). Empowering young women: What do we know? Cambridge, MA: Abdul Latif Jameel Poverty Lab.

Greenwood, C., Jenkins, A., \& Vignoles, A. (2007). The returns to qualifications in England: Updating the evidence base on Level 2 and Level 3 vocational qualifications (Discussion Paper No. CEEDP0089). UK: Centre for the Economics of Education.

Hanushek, E. A., Woessmann, L., \& Zhang, L. (2011, September). The impact of vocational education on long-run employment and earnings. Paper presented at the CESifo Area Conference on Economics of Education, Munich, Germany.

Hjort, J., Kremer, M., Mbiti, I., \& Miguel, E. (2011). Vocational education in Kenya: Demand, gender and impacts. Unpublished manuscript.

International Labour Organization. (2003). Industrial training institutes of India: The efficiency study report. New Delhi, India: Author.

Johnson, M., \& Keane, M. P. (2007). A dynamic equilibrium model of the US wage structure, 1968-1996. Unpublished manuscript.

Kambourov, G., \& Manovskii, I. (2008). Occupational specificity of human capital. Unpublished manuscript.

Kazmi, S. (2007). Vocational education and skills development: A case of Pakistan. SAARC Journal of Human Resource Development, 3, 105-117.

Krueger, D., \& Kumar, K. B. (2004a). Skill-specific rather than general education: A reason for US-Europe growth differences? Journal of Economic Growth, 9(2), 167-207. 
Krueger, D., \& Kumar, K. B. (2004b). US-Europe differences in technology-driven growth: Quantifying the role of education. Journal of Monetary Economics, 51(1), 161-190.

Pakistan, Ministry of Education, and UNESCO. (2009). Research study on technical and vocational education in Pakistan at secondary level. Islamabad, Pakistan: National Institute of Science and Technical Education.

Parey, M. (2009). Vocational schooling versus apprenticeship training: Evidence from vacancy data. Unpublished manuscript, University of Essex and Institute for Fiscal Studies, UK.

Newhouse, D., \& Suryadarma, D. (2009). The value of vocational education high school type and labor market outcomes in Indonesia (Policy Research Working Paper No. 5035). Washington, DC: World Bank.

Nopo, H., Robles, M., \& Saavedra, J. (2007). Occupational training to reduce gender segregation: The impacts of ProJoven (Research Development Working Paper No. 623). Washington, DC: Inter-American Development Bank.

World Bank. (2008). Skill development in India: The vocational education and training system (South Asian Human Development Sector Report No. 22). Washington, DC: Author. 
Annex

Table A1: MNL model: Men aged 15-60, using literacy and numeracy scores

\begin{tabular}{|c|c|c|c|c|c|c|c|c|c|c|}
\hline \multicolumn{11}{|c|}{ Probability of being... } \\
\hline & \multicolumn{2}{|c|}{ Out of the labor force } & \multicolumn{2}{|c|}{ Unemployed } & \multicolumn{2}{|c|}{ Unpaid } & \multicolumn{2}{|c|}{ Self-employed } & \multicolumn{2}{|c|}{ Wage-employed } \\
\hline & $\begin{array}{c}\text { Marginal } \\
\text { effect }\end{array}$ & z-value & $\begin{array}{c}\text { Marginal } \\
\text { effect }\end{array}$ & z-value & $\begin{array}{c}\text { Marginal } \\
\text { effect }\end{array}$ & z-value & $\begin{array}{c}\text { Marginal } \\
\text { effect }\end{array}$ & z-value & $\begin{array}{c}\text { Marginal } \\
\text { effect }\end{array}$ & z-value \\
\hline Short maths & 0.003 & 0.56 & -0.001 & -0.11 & -0.017 & $-3.17^{* * *}$ & 0.013 & 0.99 & 0.001 & 0.11 \\
\hline Short literacy & 0.000 & -0.10 & 0.007 & $1.77 *$ & 0.006 & $1.70 *$ & -0.004 & -0.50 & -0.009 & -1.02 \\
\hline Age & -0.005 & -1.27 & -0.008 & $-2.22 * *$ & -0.007 & -1.52 & 0.025 & $2.78^{* * *}$ & -0.005 & -0.59 \\
\hline Age $^{2}$ & 0.000 & $2.35 * *$ & 0.000 & $2.07 * *$ & 0.000 & 0.16 & 0.000 & $-1.95 * *$ & 0.000 & 0.03 \\
\hline Kidsunder15 & -0.001 & -0.60 & 0.000 & 0.16 & 0.006 & $3.77^{* * *}$ & 0.004 & 0.87 & -0.009 & $-1.89 *$ \\
\hline Eldove60 & 0.016 & $1.81 *$ & -0.005 & -0.61 & 0.007 & 1.04 & -0.004 & -0.19 & -0.015 & -0.79 \\
\hline Married & -0.047 & $-1.92 *$ & -0.070 & $-2.90^{* * *}$ & -0.022 & -1.37 & 0.062 & 1.56 & 0.077 & $1.97^{* *}$ \\
\hline Punjab & -0.063 & $-3.55 * * *$ & -0.030 & $-2.11^{* *}$ & 0.024 & $2.14^{* *}$ & 0.044 & 1.44 & 0.025 & 0.82 \\
\hline Urban & 0.001 & 0.04 & -0.009 & -0.77 & 0.002 & 0.15 & -0.039 & -1.29 & 0.046 & 1.48 \\
\hline Ever trained & -0.013 & -0.88 & -0.014 & -1.15 & -0.047 & $-4.03 * * *$ & 0.043 & 1.36 & 0.030 & 0.96 \\
\hline $\mathrm{N}$ & 1,449 & & & & & & & & & \\
\hline Pseudo-R² & 0.100 & & & & & & & & & \\
\hline $\begin{array}{l}\text { p (chi- } \\
\text { squared) }\end{array}$ & 0.000 & & & & & & & & & \\
\hline
\end{tabular}

Note: Robust z-statistics; ${ }^{*}=$ significant at 10 percent, ${ }^{* *}=$ significant at 5 percent, ${ }^{* *}=$ significant at 1 percent or better. Base category $=$ out of the labor force. Short maths = score on short math tests, ranging from 0 to 5 . Short literacy = score on short literacy test, ranging from 0 to 5 . 
Table A2: MNL model: Women aged 15-60, using literacy and numeracy scores

\begin{tabular}{|c|c|c|c|c|c|c|c|c|c|c|}
\hline \multicolumn{11}{|c|}{ Probability of being... } \\
\hline & \multicolumn{2}{|c|}{ Out of the labor force } & \multicolumn{2}{|c|}{ Unemployed } & \multicolumn{2}{|c|}{ Unpaid } & \multicolumn{2}{|c|}{ Self-employed } & \multicolumn{2}{|c|}{ Wage-employed } \\
\hline & $\begin{array}{c}\text { Marginal } \\
\text { effect }\end{array}$ & z-value & $\begin{array}{c}\text { Marginal } \\
\text { effect }\end{array}$ & z-value & $\begin{array}{c}\text { Marginal } \\
\text { effect }\end{array}$ & z-value & $\begin{array}{c}\text { Marginal } \\
\text { effect }\end{array}$ & z-value & $\begin{array}{c}\text { Marginal } \\
\text { effect }\end{array}$ & z-value \\
\hline Short maths & -0.060 & $-4.89 * * *$ & 0.023 & $2.48^{* *}$ & 0.006 & 1.21 & 0.004 & 0.84 & 0.027 & $4.63^{* * *}$ \\
\hline Short literacy & 0.017 & $2.56^{* *}$ & 0.001 & 0.15 & -0.016 & $-4.43^{* * *}$ & -0.004 & $-1.73 *$ & 0.002 & 0.68 \\
\hline Age & -0.021 & $-3.38^{* * *}$ & 0.006 & 1.38 & -0.001 & $1.89 *$ & 0.006 & $2.44^{* *}$ & 0.009 & $3.36^{* * *}$ \\
\hline Age $^{2}$ & 0.000 & $3.29^{* * *}$ & 0.000 & -1.47 & 0.000 & 0.23 & 0.000 & $-2.37^{* *}$ & 0.000 & $-2.88^{* * *}$ \\
\hline Kidsunder15 & -0.012 & $-3.92 * * *$ & 0.005 & $2.46^{* *}$ & 0.005 & $3.60 * * *$ & -0.001 & -0.56 & 0.003 & $2.47^{* *}$ \\
\hline Eldove60 & 0.022 & $1.71 *$ & 0.004 & 0.41 & 0.003 & 0.45 & -0.007 & -1.27 & -0.022 & $-3.69 * * *$ \\
\hline Married & 0.142 & $4.94^{* * *}$ & -0.057 & $-2.61 * *$ & 0.002 & 0.13 & -0.038 & $-2.84^{* * *}$ & -0.048 & $-3.26 * * *$ \\
\hline Punjab & -0.185 & $-9.15^{* * *}$ & 0.023 & 1.57 & 0.102 & $9.08^{* * *}$ & 0.034 & $4.28^{* * *}$ & 0.026 & $3.08^{* * *}$ \\
\hline Urban & 0.078 & $3.52^{* * *}$ & -0.027 & $-1.78 *$ & -0.072 & $-6.69 * * *$ & 0.020 & $1.99^{* *}$ & 0.003 & 0.29 \\
\hline Ever trained & -0.151 & $-5.87^{* * *}$ & -0.009 & -0.57 & 0.032 & $2.64^{* * *}$ & 0.085 & $5.23^{* * *}$ & 0.044 & $3.48^{* * *}$ \\
\hline $\mathrm{N}$ & 1,922 & & & & & & & & & \\
\hline Pseudo-R ${ }^{2}$ & 0.131 & & & & & & & & & \\
\hline $\begin{array}{l}\text { p (chi- } \\
\text { squared) }\end{array}$ & 0.000 & & & & & & & & & \\
\hline
\end{tabular}

Note: Robust $z$-statistics; ${ }^{*}=$ significant at 10 percent, ${ }^{* *}=$ significant at 5 percent, ${ }^{* * *}=$ significant at 1 percent or better. Base category $=$ out of the labor force. Short maths = score on short math tests, ranging from 0 to 5 . Short literacy = score on short literacy test, ranging from 0 to 5. 
Table A3: Household fixed-effects estimates for wage- and selfemployed individuals (aged 15-60) by gender

\begin{tabular}{|c|c|c|c|c|c|c|}
\hline \multirow[b]{2}{*}{ Ln(earnings) } & \multicolumn{3}{|c|}{ Male } & \multicolumn{3}{|c|}{ Female } \\
\hline & Coefficient & t-value & & Coefficient & t-value & \\
\hline Education & 0.002 & 0.16 & & 0.036 & 1.00 & \\
\hline Age & 0.096 & 4.03 & $* * *$ & 0.035 & 0.66 & \\
\hline Age $^{2}$ & -0.001 & -3.84 & $* * *$ & 0.000 & -0.58 & \\
\hline Ever trained & 0.100 & 0.95 & & 0.443 & 1.76 & * \\
\hline Constant & 9.148 & 22.85 & $* * *$ & 9.001 & 10.20 & $* * *$ \\
\hline Number of observations & 751 & & & 78 & & \\
\hline Number of groups & 328 & & & 35 & & \\
\hline $\mathrm{R}^{2}$ & 0.100 & & & 0.100 & & \\
\hline
\end{tabular}

Note: ${ }^{*}=$ significant at 10 percent, ${ }^{* *}=$ significant at 5 percent, ${ }^{* * *}=$ significant at 1 percent or better. Base category $=$ out of the labor force. 